\title{
MITTEILUNGEN
}

\section{Some Effects of the Atlantic Circulation and of River Discharges on the Residual Girculation of the North Sea}

UDC 551.465.55:551.465.11; North Sea

\begin{abstract}
Summary
In a previous paper the simulation of the tidal and wind generated mean residual circulation in the North Sea was studied, with special references to pollution problems. In that paper, the influence of the Atlantic circulation on the North Sea has been neglected. Referring to the above mentioned paper, in this study the net inflow via the Dover Strait, Kattegat and rivers is simulated in the model. The model runs were repeated, yielding a significant improvement in comparison with observed data.
\end{abstract}

\section{Auswirkungen der Atlantischen Zirkulation und der Süßwasser-Abflüsse auf die Rest- strom-Zirkulation der Nordsee (Zusammenfassung)}

In einer früheren Veröffentlichung wurde die Simulation der durch mittlere Wind- und Gezeitenanregung verursachten Reststrom-Zirkulation in der Nordsee im Hinblick auf Verschmutzungsprobleme beschrieben und diskutiert. Dabei wurden Einströmungen von außerhalb der Nordsee vernachlässigt. In der vorliegenden Arbeit wird, bezugnehmend auf die o.a. Veröffentlichung, der Einstrom durch die Doverstraße, durch Kattegat und durch Flüsse im Modell berücksichtigt. Die Resultate einiger Wiederholungsrechnungen zeigen eine eindeutige Verbesserung im Vergleich mit Naturmessungen.

In a previous paper, which will be referred to as paper $A$ in this text, the author presented a model of the residual circulation in the North Sea (Maier-Reimer [1977], see also for further references). In that model, the circulation was driven only by the $\mathrm{M}_{\mathbf{2}}$-tide and an annual mean wind stress field. The restriction on annual mean conditions in a vertically integrated model yields rather small residual velocities which cannot be compared, for instance, with surface velocities averaged over a lunar day. The net inflow through the Dover Straits was computed to be $2 \cdot 10^{4} \mathrm{~m}^{3} / \mathrm{s}$ which is obviously too small; it should be an order of magnitude higher (Otto [1976]).

One possible explanation of this lack can be seen in the neglected general circulation of the Atlantic Ocean. Wegner's compilation (Wegner [1973]) of the absolute topography of the mean water level indicates a difference of $10 \mathrm{~cm}$ to $20 \mathrm{~cm}$ between the water level in the Channel and at the northern boundary of the North Sea. In order to investigate the effect of this surface slope on the North Sea circulation, the model was re-run under the same conditions as before, rajsing only the mean water level in the Dover Straits by $10 \mathrm{~cm}$. As in A, the residual velocity $\bar{U}$ was derived from the instantaneous velocities $\boldsymbol{U}$ according to

$$
\overline{\boldsymbol{U}}=\frac{\int H \boldsymbol{U} \mathbf{d} t}{\int H \mathrm{~d} t}
$$

where $H$ is the water depth.

The result shows a strong enhancement of the net inflow up to $1.3 \cdot 10^{5} \mathrm{~m}^{3} / \mathrm{s}$ which is in a good agreement with the value given by Otto. In the main part of the North Sea model, 
the circulation (Fig. 1) turns out to be quite similar as in the former experiment (paper A, Fig. 6); in general there are slightly higher velocities involved. This increase causes a decrease of the computed flushing times (as in paper A, in this paper the flushing time is defined as a

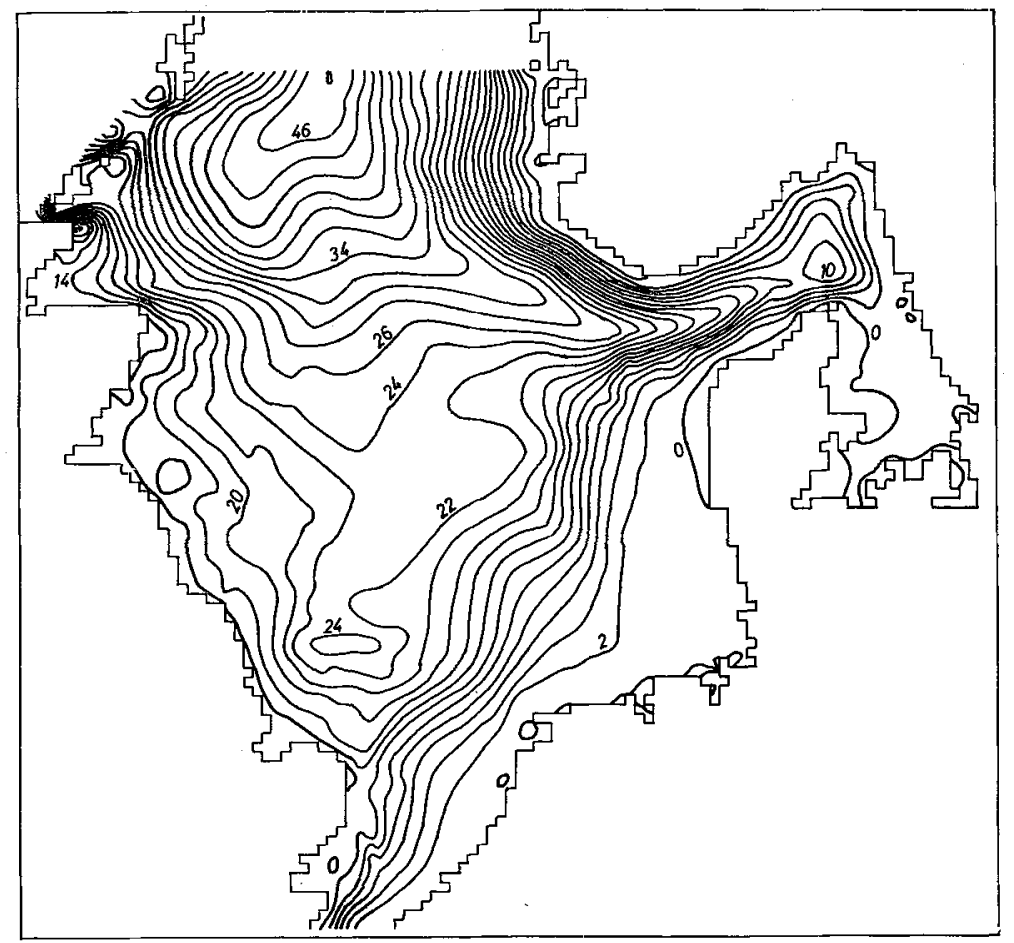

Fig. 1. Mean transport $\left(10^{4} \mathrm{~m}^{3} \mathrm{~s}^{-1}\right)$ stream-function defined as $\int V \mathrm{~d} x$ resulting from $\mathrm{M}_{2}$-tide, annual mean wind stress and mean surface slope $10 \mathrm{~cm} / 1000 \mathrm{~km}$

function of spatial coordinates, giving the time which a particle would need to leave the North Sea). In nearly all parts of the area covered by the model they are reduced by approximately one year (Fig. 2 and Fig. 11, paper A).

A calculation of the spreading of $\mathrm{Cs}^{137}$, released in Cherbourg, yields a stronger spreading rate than described in paper $A$, but the general pattern remained unaltered and is still fitting well into Kautsky's data (paper A, Fig. 9 and 10).

Although the computed flushing times in the German Bight were reduced by the increased inflow through the Straits of Dover, they still seem to be too high in comparison with observational data.

Another run was carried out, incorporating a horizontal diffusion coefficient of $25 \mathrm{~m}^{2} / \mathrm{s}$. This was done using the same stochastic procedure (Maier-Reimer [1975]) as for the spreading of $\mathrm{Cs}^{137}$, starting with 5 particles at each starting point. The plotted flushing time for this run was defined as the average time the 5 particles needed. Due to the low number of particles, the statistical fluctuations introduce additional errors on the isochrones. The results (Fig. 3) are very similar to those of the previous run for nearly all parts of the North Sea, except for the German Bight and other portions of closed streamlines, where a decrease in the computed flushing time now fits better into the data at hand.

In a third experiment, some river discharges and the Baltic current were incorporated into the model. The discharge rates are crude approximations to the values given by Grindley (Grindley [1972]). The pattern of the stream function (Fig. 4) seems to be nearly identical to the previous one. Just the absolute values are changed by the inflow rates. The effect on 


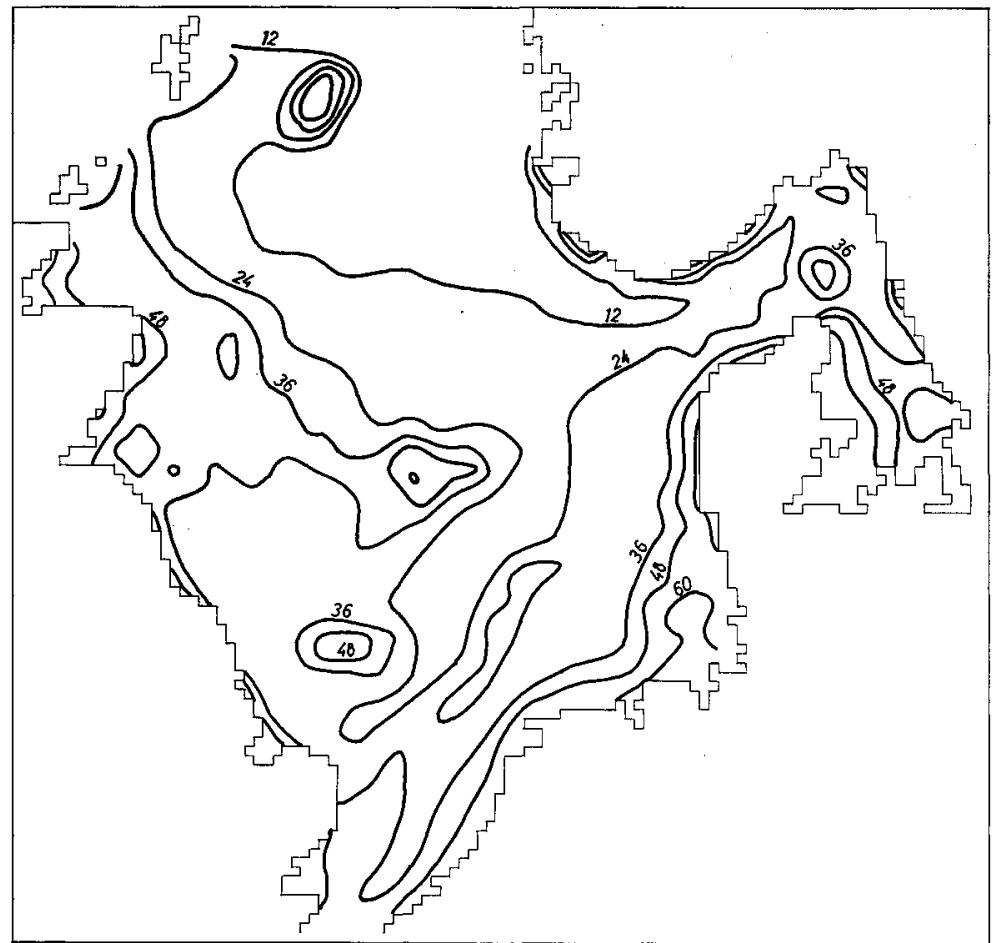

Fig. 2. Flushing time in month computed using the stream-function of Fig. 1

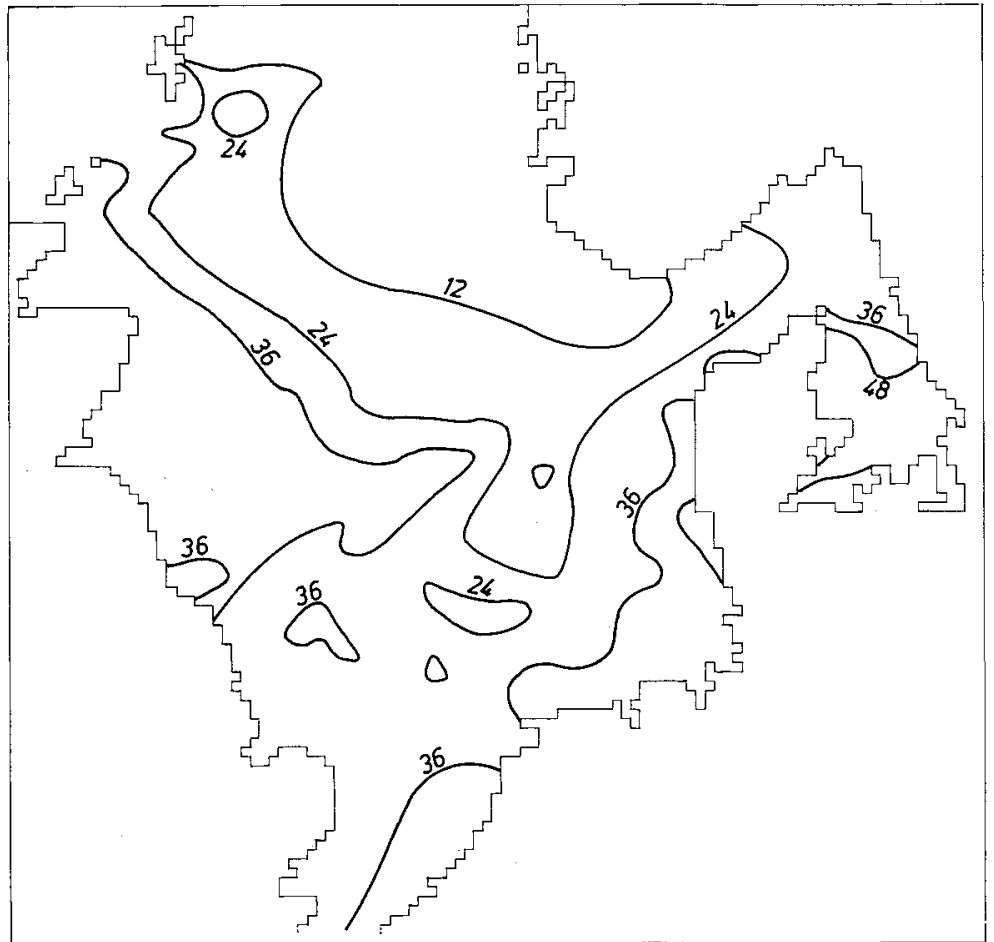

Fig. 3. Flushing time in month as compiled using the stream-function of Fig. 1 and a constant diffusion rate of $25 \mathrm{~m}^{2} \mathrm{~s}^{-1}$ 


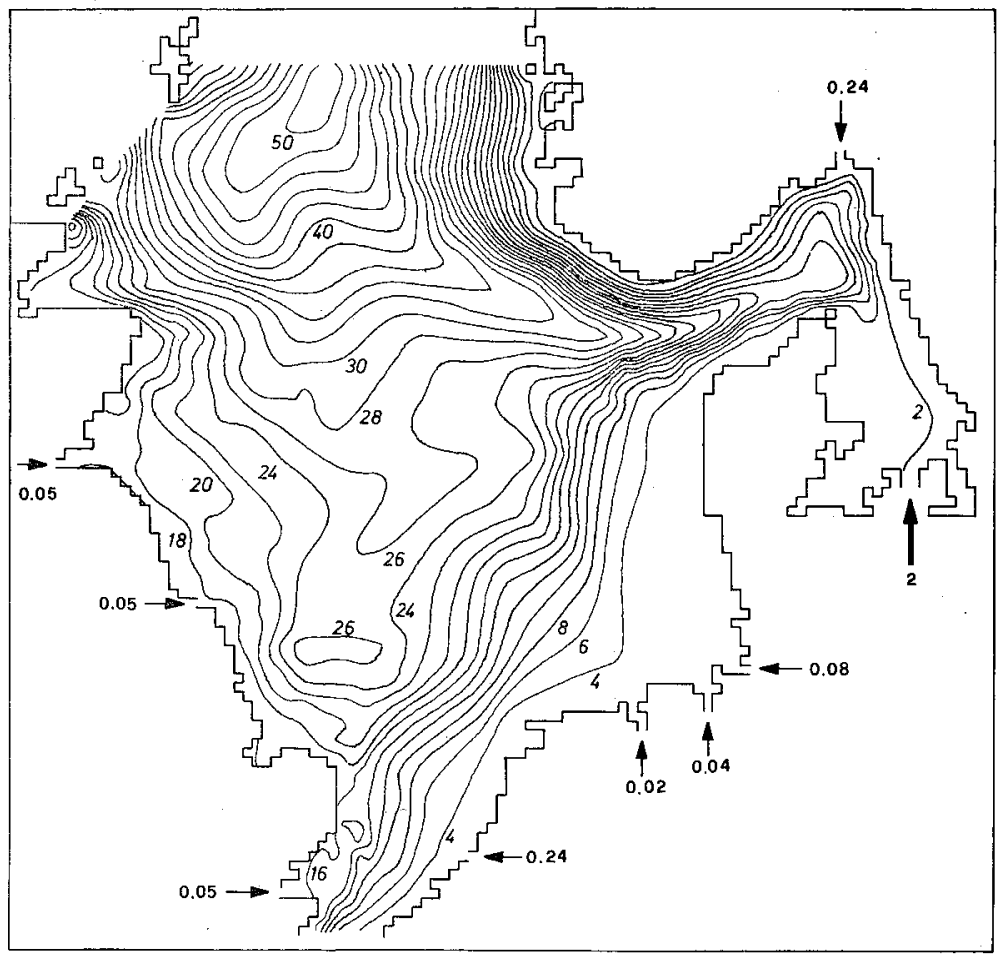

Fig. 4. Stream-function as in Fig. 1, including river discharges in $10^{4} \mathrm{~m}^{3} \mathrm{~s}^{-1}$

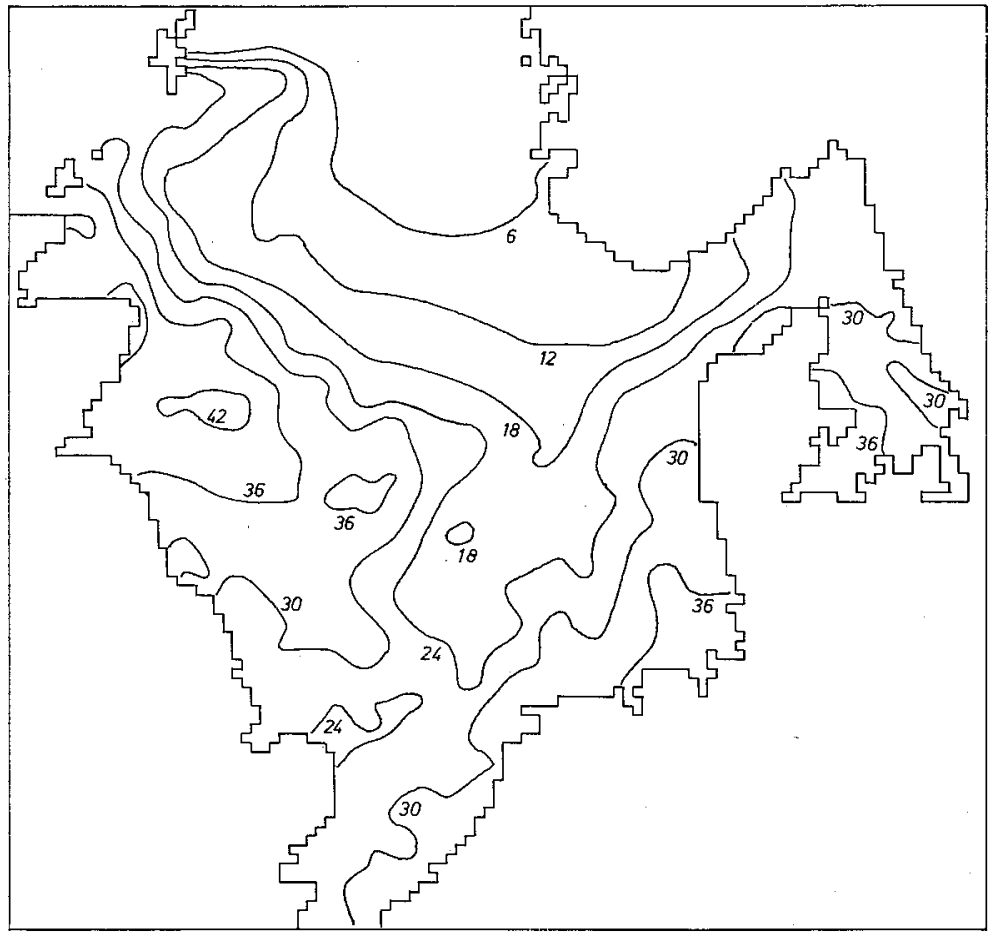

Fig. 5. Flushing time in month resulting from the stream function of Fig. 4 using a diffusion coefficient of $25 \mathrm{~m}^{2} \mathrm{~s}^{-1}$ 
the flushing time, however, is rather pronounced. Along the Mid-European coasts, the flushing time is reduced by approximately 6 months. As a conclusion it may be stated that this last experiment seems to be the most realistic one, regarding the boundary conditions as well as the results.

\section{References}

Grindley, J., 1972: Hydrology of the North Sea: run-off and precipitation. Met. Mag., London. 101, 356-362.

Maier-Reimer, E., 1975: Zum Einfluß eines mittleren Windschubes auf dio Restströme der Nordsee. Dt. hydrogr. Z. 28, 253-262.

Maier-Reimer, E., 1977: Residual circulation in the North Sea due to the $\mathrm{M}_{2}$-tide and mean annual wind stress. Dt. hydrogr. Z. 30, $69-80$.

Otto, L., 1976: Problems in the application reservoir theory to the North Sea. ICES C.M. $1976 /$ C:18.

Wegner, G., 1973: Geostrophische Oberflächenströmung im nördlichen Nordatlantischen Ozean im Internationalen Geophysikalischen Jahr 1957/58. Ber. Dt. wiss. Kommiss. Meeresforsch. 22, 411-426.

Ernst Maier-Reimer

Eingegangen im Oktober 1978

Anschrift des Verfassers:

Dr. Ernst Maier-Reimer, Max-Planck-Institut für Meteorologie, Bundesstraße 55, 2000 Hamburg 13 